\title{
Phase Transformation of $\mathrm{MnCO}_{3}$ surfaces within Nanometric Water Films
}

\author{
TAN N. LUONG ${ }^{1}$, EUGENE S. ILTON ${ }^{2}$, ANDREY \\ SHCHUKAREV $^{1}$ AND JEAN-FRANÇOIS BOILY ${ }^{1}$ \\ ${ }^{1}$ Department of Chemistry, Umeå University \\ ${ }^{2}$ Pacific Northwest National Laboratory \\ Presenting Author: tan.luong@umu.se
}

Phase transformations at mineral surfaces have been widely investigated in liquid water, yet those that occur within nanometrically-thick water films formed by exposure to atmospheric moisture continue to be misunderstood. The study of reactions within these confined environments is directly relevant to a score of processes in nature, including atmospheric cloud formation, chemical weathering, and vadose zone biogeochemistry.

In this work, we monitored the phase transformation of rhodochrosite $\left(\mathrm{MnCO}_{3}\right)$ within the confines of nanometricallythick water films. We find that $\mathrm{Mn}^{\mathrm{III}} / \mathrm{Mn}^{\mathrm{IV}}$-oxides coatings form in water films of no less than $\sim 10$ monolayers when exposed to ambient conditions of $\mathrm{CO}_{2}$ and $\mathrm{O}_{2}$. Vibrational spectroscopy, $\mathrm{X}$ ray diffraction, X-ray photoelectron spectroscopy and Transmission Electron Microscopy collectively provide evidence for the transformation surface $\mathrm{Mn}(\mathrm{II})$ species to nanosized hausmannite $\left(\mathrm{Mn}_{3} \mathrm{O}_{4}\right)$ and birnessite $\left(\delta-\mathrm{MnO}_{2}\right)$, however only in alkaline films. We explain this transformation by the homogenous oxidation of hydrolyzed $\mathrm{Mn}(\mathrm{II})$ aqueous species, and their subsequent precipitation to $\mathrm{Mn}^{\mathrm{III}} / \mathrm{Mn}^{\mathrm{IV}}$-oxides nanoparticles all within the confines of $\sim 10$ monolayer-thick water films. Although rhodochrosite is strongly resilient to surface oxidation under ambient conditions, hikes in water film $\mathrm{pH}$ during dehydration events in environments exposed to wetdry cycling, especially at oxic/anoxic boundaries, could produce these new reactive $\mathrm{Mn}^{\mathrm{III}} / \mathrm{Mn}^{\mathrm{IV}}$-oxides nanoparticle coatings. 